\title{
Effects of cadmium chloride on some endocrine glands (thyroid and adrenal) in male rats (Rattus norvegicus)
}

\author{
K.H. Al- Derawi \\ Biology Department, College of Science, University of Basra, Iraq, Email: karimhalderawi59@gmail.com
}

(Received February 15, 2018; Accepted March 18, 2018)

\begin{abstract}
This study was designed to evaluate the cytotoxic effects of cadmium chloride $\left(\mathrm{CdCl}_{2}\right)$ on thyroid and adrenal gland of male rats (Rattus norvegicus). Thirty six male rats were used and randomly into three groups each of 12 rats, the first group(G1) kept as at control. The 2nd and 3rd groups (G2 and G3) were administrated orally $\mathrm{cdcl}_{2}$ at doses of 15 and 20 $\mathrm{mg} / \mathrm{kg}$.B.W. respectively for 6 weeks. After the treatment period, the rats were sacrificed, then thyroid and adrenal glands were removed and processed for light microscope. Light microscopic examination of thyroid gland with $(15 \mathrm{mg} / \mathrm{kg} . \mathrm{B}$.W.) showed increase in the size of follicles, some of these follicles appeared empty from any colloidal substance and heavily infiltrated by inflammatory cells, with depletion of parafollicular cells. Vaculated follicles may be clear in other sections, and showed congested blood vessels, vascularized stroma, hyperplasia of thyrocyte in rats treated with $20 \mathrm{mg} / \mathrm{kg}$.B.w. Results also noted changes in different regions of adrenal gland related to rats exposure tocdcl ${ }_{2}$ with $15 \mathrm{mg} / \mathrm{kg}$.B.W., these includes cellular debris, necrosis of cortical cells, amorphous material in the zona fasciculate and focal necrosis in zona granulosa with disruption of normal structure and replaced by necrotic cells and inflammatory cells, also obvious adipocytes infiltration which appeared clear in medulla. Most changes occurred within the adrenal cortex and appeared more severity than that in the medulla region. Hypereosinophilia, pyknotic nuclei, congested blood vessels, hemorrhage, degeneration and inflammation also seen in both regions (cortex and medulla) of adrenal gland from rat exposed to $\mathrm{cdcl}_{2}$ at $20 \mathrm{mg} / \mathrm{kg}$. B.W.
\end{abstract}

Keywords: Cadmium chloride, Thyroid gland, Adrenal gland, Effect, Rats

Available online at http://www.vetmedmosul.com

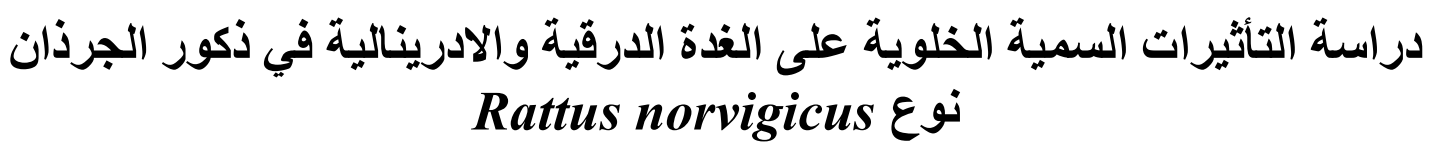

$$
\begin{aligned}
& \text { كريم هلال ثنامر الايراوي } \\
& \text { قسم علوم الحياة، كلية العلوم، جامعة البصرة، العراق }
\end{aligned}
$$

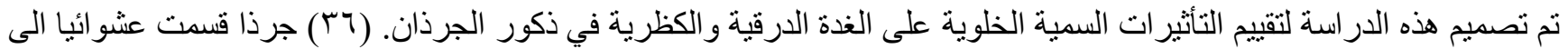

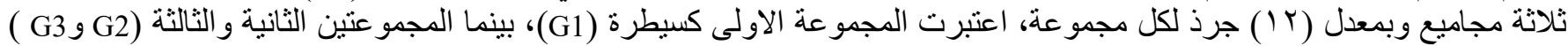

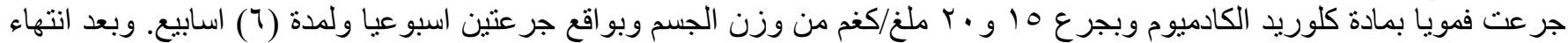

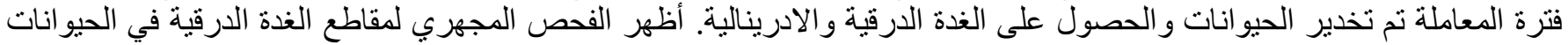

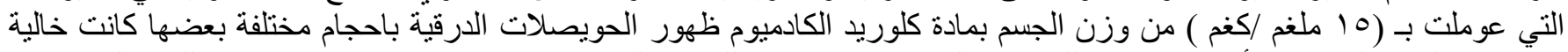

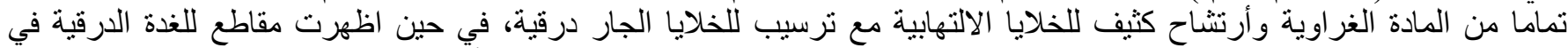

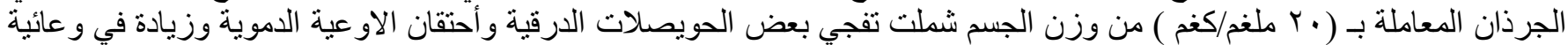

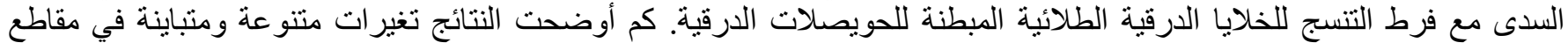




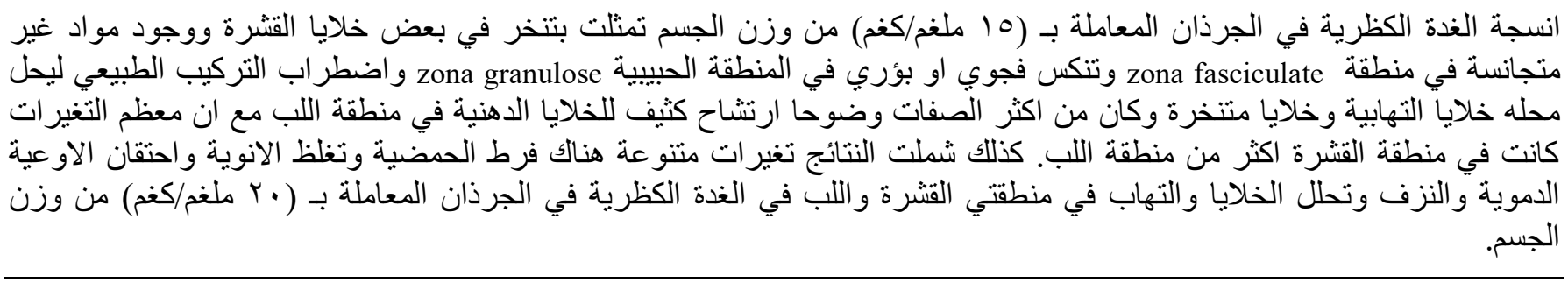

\section{Introduction}

Cadmium ( $\mathrm{Cd}$ ) considered to be the most toxic environmental and occupational pollutants $(1,2)$. Although, the harmful effects $\mathrm{Cd}$ exposure have been extensively investigated in humans and experimental animals, many effects and mechanisms of the action still not fully understood and therefore further studies are needed. The accumulation of $\mathrm{Cd}$ occurs in the mitochondria of thyroid follicular epithelial cells and inhibits both the synthesis and release of thyroid hormones (3). Furthermore, Cadmium appears to be the main cause of auto-immune thyroid disease (4). Cd can be define as a toxic heavy metal that has short and long term effects. It accumulates mainly in blood, kidney, liver, brain, testis, the reproductive organs, the hypothalamus and in the mammalian pituitary gland $(5,6)$. Other Cd effects includes it's influence on cell physiology and growth $(7,8)$ and on the induction of lipid peroxidation (LPO), that is dependent on oxygen free radicals $(9,10)$. Adding to its well-known toxic effects, $\mathrm{Cd}$ is now considered as potential endocrine disruptor as well $(11,12)$.

The endogenous hormones can be mimicked, enhanced or inhibited by naturally or synthesized agents known as Endocrine disrupting chemicals (EDCs) (13). Cd Exposure is accompanying with the activity of endocrine system in both genders in rats (14). Cd can perform as an endocrine disruptor, its action involves altering the homeostatic balance of a variety of hormones. Reports of Circulating concentrations of pituitary hormones, for example, prolactin, adrenocorticotropin hormone, growth hormone, luteinizing hormone, follicle-stimulating hormone, and thyroid-stimulating hormone showed an alteration in male rats exposed to $\mathrm{Cd}(8)$.

\section{Materials and methods}

\section{Experimental animals}

Male rats Rattus norvigicus weighting (160-180 g) were purchased from animals house of college of Science, Basrah University. The animals were kept within standard conditions (pallat and water ad libitum) and a 12: $12 \mathrm{hrs}$. light-dark cycle.

\section{Experimental design}

A total number of 36 male rats were divided into 3 groups, each group consist of 12 rats. The control group G1 treated with distilled water orally. Animals of G2 and G3 were given $15 \mathrm{mg} / \mathrm{kg}$. B.W. and $20 \mathrm{mg} / \mathrm{kg}$.bw.mg $/ \mathrm{kg} / \mathrm{B} . \mathrm{W}$. of cadmium chloride $\left(\mathrm{cdcl}_{2}\right)$, respectively. The doses of $\mathrm{cdcl}_{2}$ were prepared as fresh in distilled water and $0.3 \mathrm{ml}$ was administered orally twice a week. All animals of G2 and G3 groups were treated only orally for a week at the beginning of the experiment. After (6) weeks, the male rats were anesthetized with ether. The thyroid and adrenal glands were removed from all animals and were immediately fixed in $10 \%$ neutral buffered formalin fixative. Then, routine histological procedures were done (15), and histological sections of all organs were stained with Hematoxylin and Eosin stains.

\section{Results}

\section{Histological examination of thyroid gland}

Sections from thyroid gland of the control rats showed thyroid follicles surrounded by dense fibrous connective tissue, band of connective tissue extend to separate between the follicles and part of trachea (hyaline cartilage) always appeared (fig.1). Each follicle lined by epithelial cells which arranged from columnar, cuboidal to squamous cells and these follicles are completely filled with colloid substance (fig. 2).

Light microscopic observations of the section from thyroid gland of rats treated with $15 \mathrm{mg} / \mathrm{kg} . \mathrm{bw} . \mathrm{CdCl}_{2}$ showed different sizes of thyroid follicles, some of these follicles appeared to be hollow with (no colloidal substance), heavy infiltration of inflammatory cells, depletion of parafollicular cells and vacuolated colloid may be clear on other sections (fig. 3 and 4). The thyrocytes arranged in acinar manner, the colloid was vacuolated and some follicles with scantly colloid (fig. 5). Sections of thyroid gland from rats treated with $20 \mathrm{mg} / \mathrm{kg}$.B.W. $\mathrm{CdCl}_{2}$ showed irregular thyroid follicles with very scantly colloid materials, exfoliation of lining cells with lumen follicles noticed, congested blood vessels, vascularized stroma, hyperplasia of thyrocytes and most follicles were empty (fig. 6, 7 and 8). 


\section{Histological examination of adrenal gland.}

The control sections of adrenal gland showed a normal histologically features (cortex and inner layer medulla). The cortex contains paranchymal cells and subdivided into zona glomerulosa, zona fasciolata and zona reticularis (fig. 9). The glomeulosa consists of small columnar cells that arranged in cords and clusters, while the fasciculata appeared as larger cells and vacuolated known as spongiocytes with lipid droplets. Furthermore, the sections showed the inner layer of cortex known the reticularis which is formed from smaller cells resemble the spongiocytes but with less lipid droplets (fig. 10).

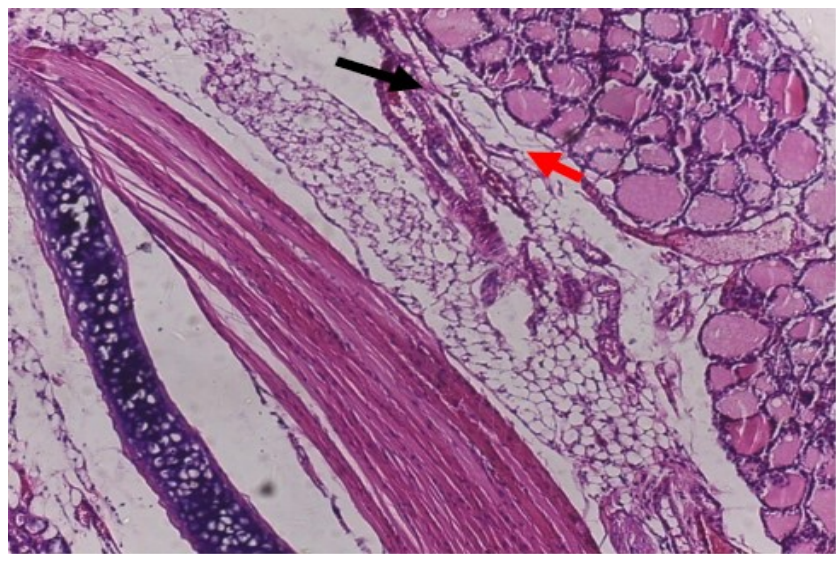

Fig. 1: Microphotograph of thyroid gland from control rats showing septa of connective tissue $\rightarrow$ and collagenous fibers $\rightarrow$ (H\&E, 200X).

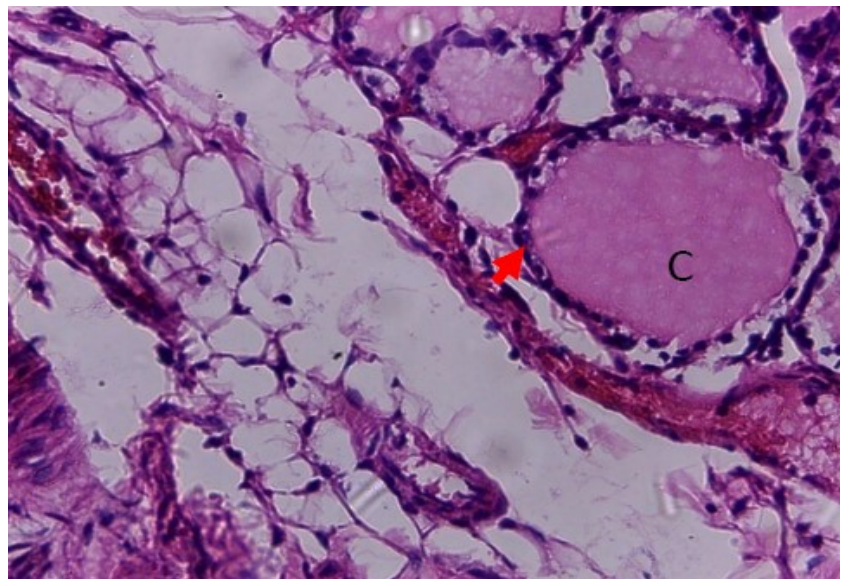

Fig. 2: Microphotograph of thyroid gland from control rats showing each follicle lining with follicular epithelium $\rightarrow$ and follicle filled with colloid substance (C), (H\&E 400X).

The medulla is invested by the cortex and occupied the central portion of the adrenal gland. Results of the adrenal gland from rats exposed to $15 \mathrm{mg} / \mathrm{kg}$.B.W. $\mathrm{CdCl}_{2}$ showed changes in different regions including cellular debris, necrosis of cortical cells, amorphous material in the replaced necrotic cells and inflammatory cells infiltration (fig. 11, 12 and 13). Furthermore, the most obvious feature of this group is the infiltration of adipocytes which appeared very clear in the medulla (fig. 14). Most changes occur within the adrenal cortex and they appeared to be more severe than the changes in the medulla. Sections from the adrenal gland of rats treated with dose $20 \mathrm{mg} / \mathrm{kg}$.B.W. $\mathrm{CdCl}_{2}$ showed variable changes ranging from hypereosinophilia, pyknosis nuclei, congested blood vessels and hemorrhage (fig. 15 and 16). Moreover, degeneration and inflammation was very clear in both the cortex and medulla of this group (fig. 17 and 18).

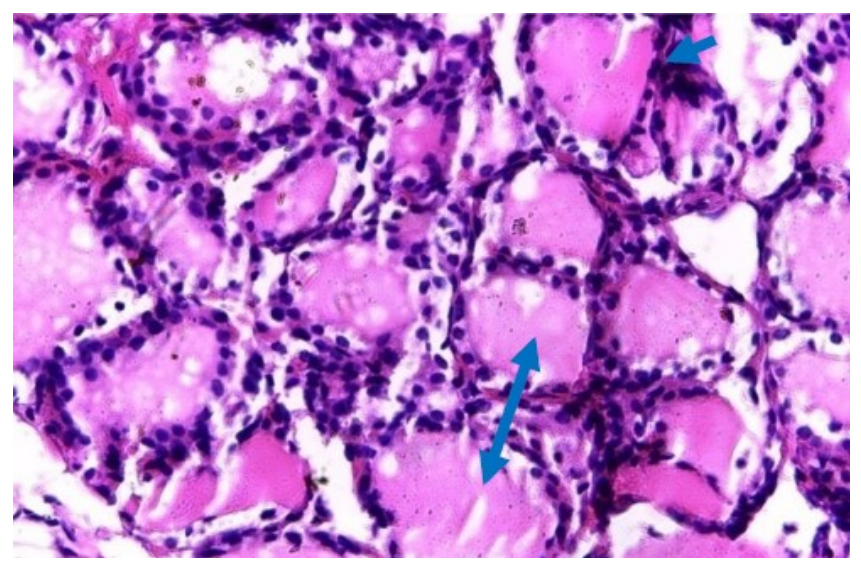

Fig. 3: Microphotograph of thyroid gland from treated rats with $15 \mathrm{mg} / \mathrm{kg} . \mathrm{bw}$. of cdcl 2 after 6 weeks showing heavy infiltration of inflammatory cell $\rightarrow$ and disorganized thyroid follicles $\Longleftrightarrow$ (H\&E 400X).

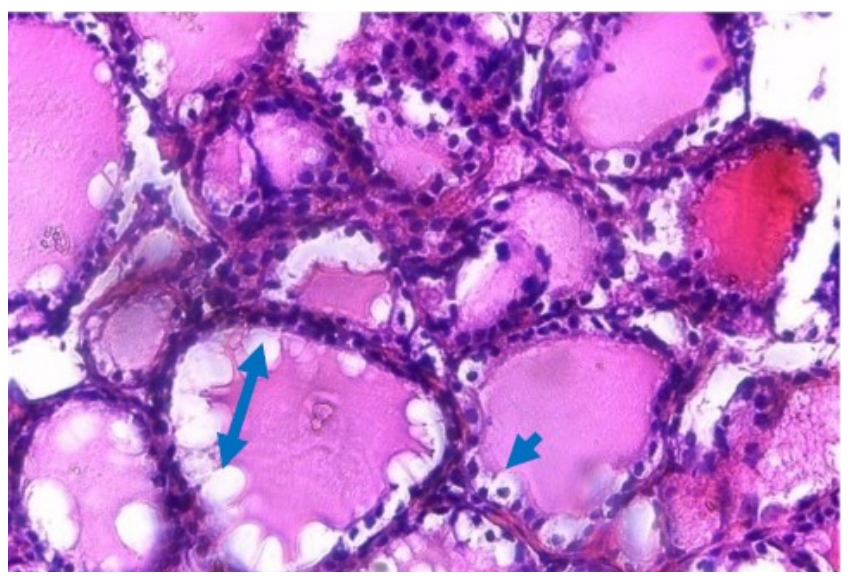

Fig. 4: Microphotograph of thyroid gland from treated rats with $15 \mathrm{mg} / \mathrm{kg} . b w$. of cdcl 2 after 6 weeks showing vaculated colloid $\longleftrightarrow$ and depletion of parafollicular cells $\rightarrow(\mathrm{H} \& \mathrm{E} 400 \mathrm{X})$. 


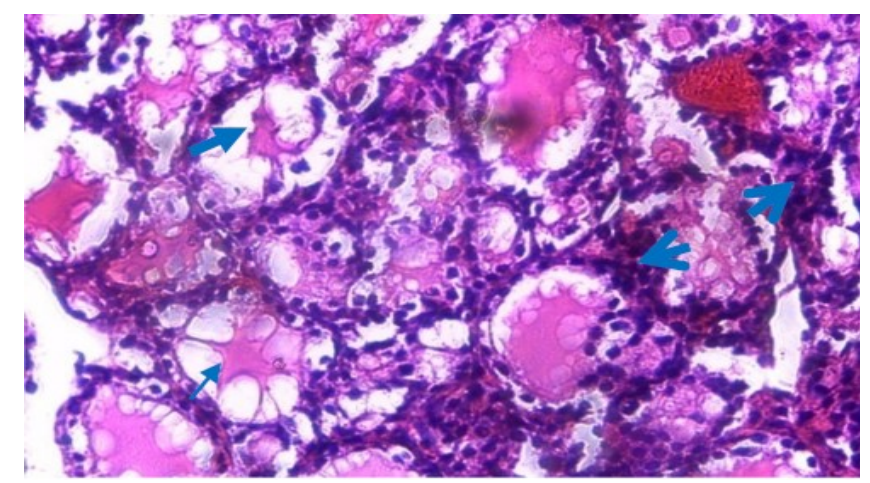

Fig. 5 Microphotograph of thyroid gland from treated rats with $15 \mathrm{mg} / \mathrm{kg} . \mathrm{bw}$. of cdcl2 after 6 weeks showing the thyrocytes arranged acina $r \geqslant$, the colloid was vaculized $\Rightarrow$ and some of follicles with scantly colloid (H\&E, 400X).

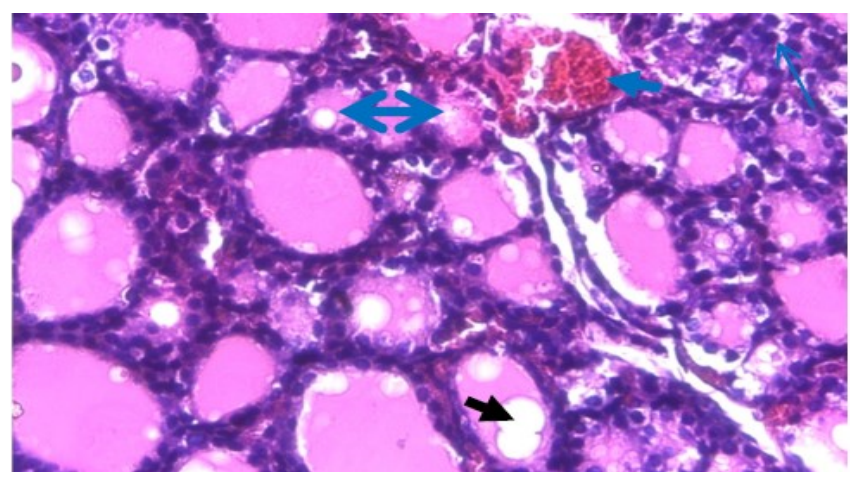

Fig. 6: Microphotograph of thyroid gland from treated rats with $20 \mathrm{mg} / \mathrm{kg} . \mathrm{bw}$. of cdcl 2 after 6 weeks showing reduced in follicles size $\longleftrightarrow$, congested blood vessels $\longrightarrow$, vaculated colloid substance $\rightarrow$ and hyperplasia of thyrocytes $\geqslant(\mathrm{H} \& \mathrm{E}, 400 \mathrm{X})$.

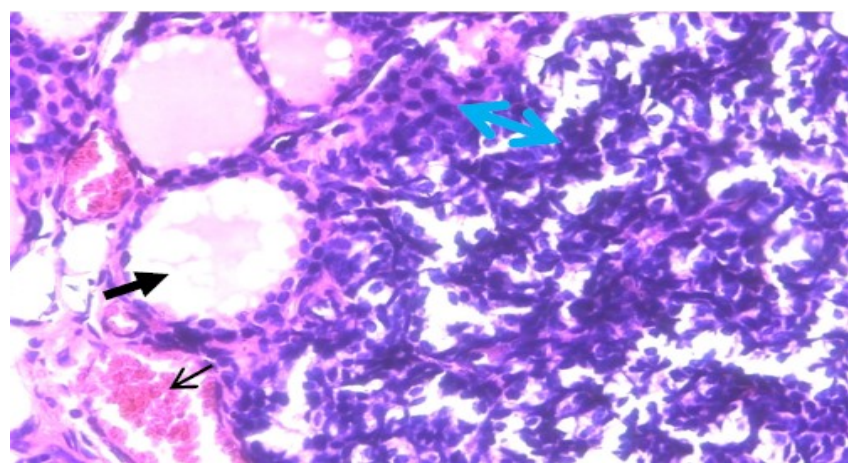

Fig. 7: Microphotograph of thyroid gland from treated rats with $20 \mathrm{mg} / \mathrm{kg} . \mathrm{bw}$. of cdcl 2 after 6 weeks showing infiltration with inflammatory cells $\longleftrightarrow$, most follicles empty $\rightarrow$ and congested blood vessels $\rightarrow$ (H\&E, 400x).

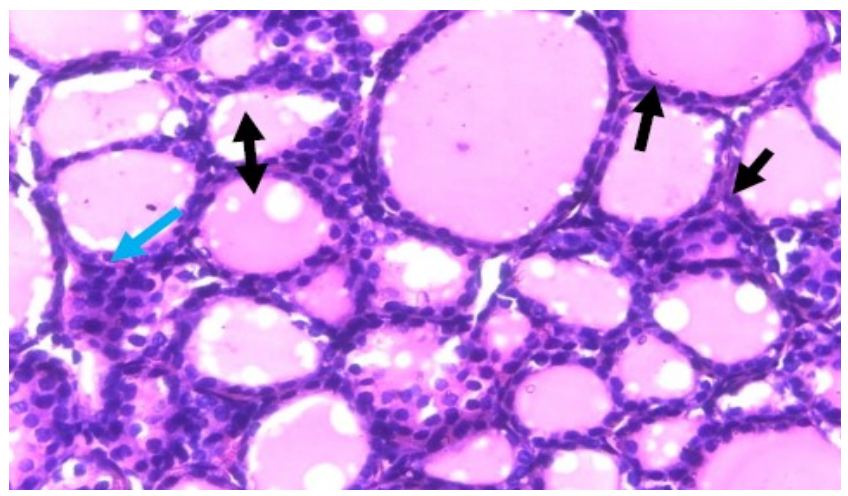

Fig. 8: Microphotograph of thyroid gland from treated rats with $20 \mathrm{mg} / \mathrm{kg}$.bw. of cdcl 2 after 6 weeks showing variable size of follicles $\leftrightarrow$, thickness of stroma $\rightarrow$ and depletion of inflammatory cells $\rightarrow$ (H\&E, 400x).

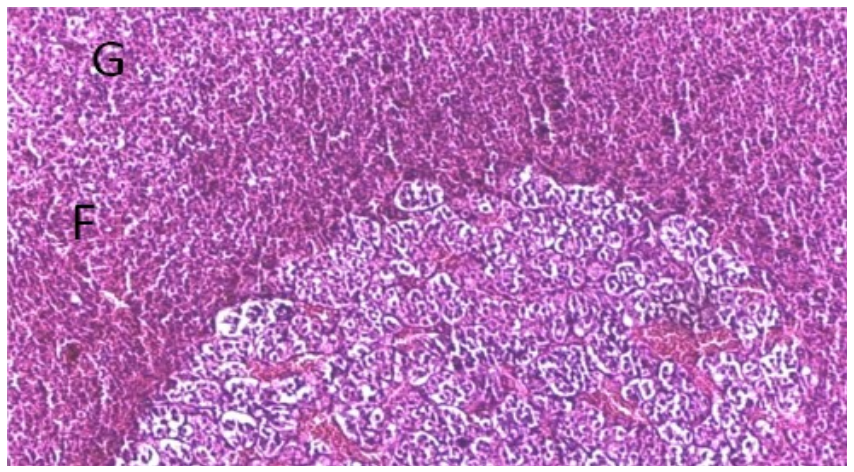

Fig. 9: Microphotograph of adrenal gland from control rats showing inner layer known medulla (M) and outer layer subdivided into fasciculata (F), glomerulosa (G) and reticularis $(\mathrm{R})$. (H\&E, 200x).

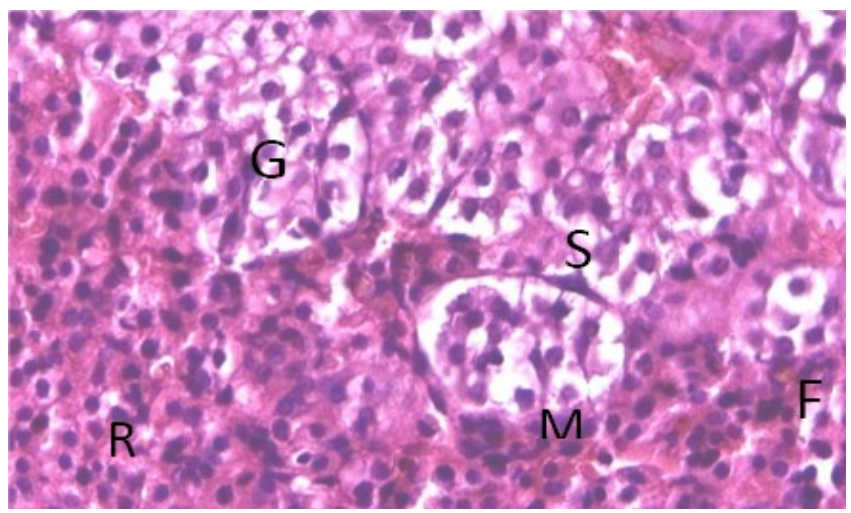

Fig. 10: Microphotograph of adrenal gland from control rats showing spongiocytes $(\mathrm{S})$, fasciculata $(\mathrm{F})$ and glomerulosa (G). (H\&E, 400x). 


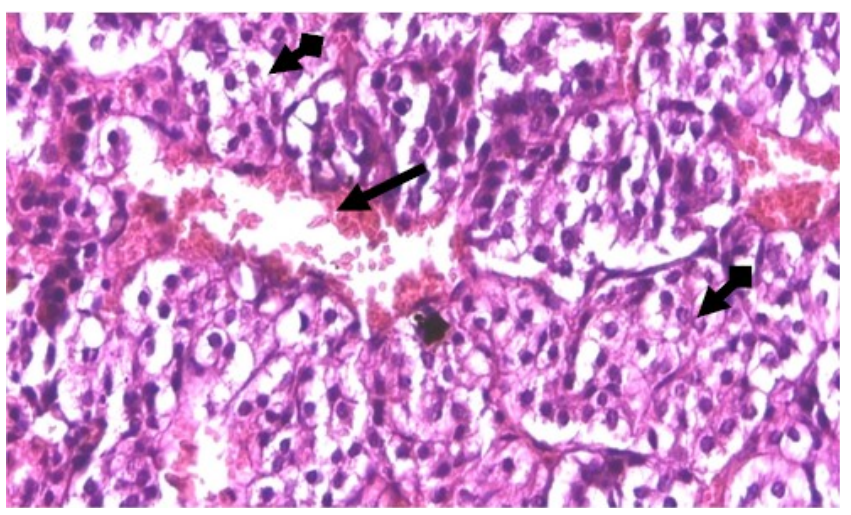

Fig. 11: Microphotograph of adrenal gland from treated rats with $15 \mathrm{mg} / \mathrm{kg}$.bw. showing necrosis $\longrightarrow$ and congested blood vessels $\rightarrow$ (H\&E, 400x).

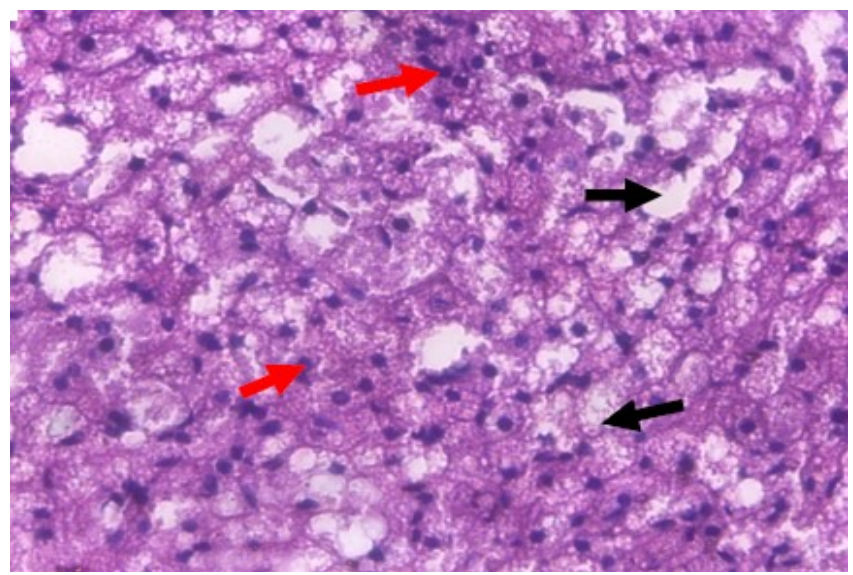

Fig. 12: Microphotograph of adrenal gland of rats treated with $15 \mathrm{mg} / \mathrm{kg}$.bw. showing necrosis $\rightarrow$ and infiltration of inflammatory cells $\rightarrow$ (H\&E, 400x).

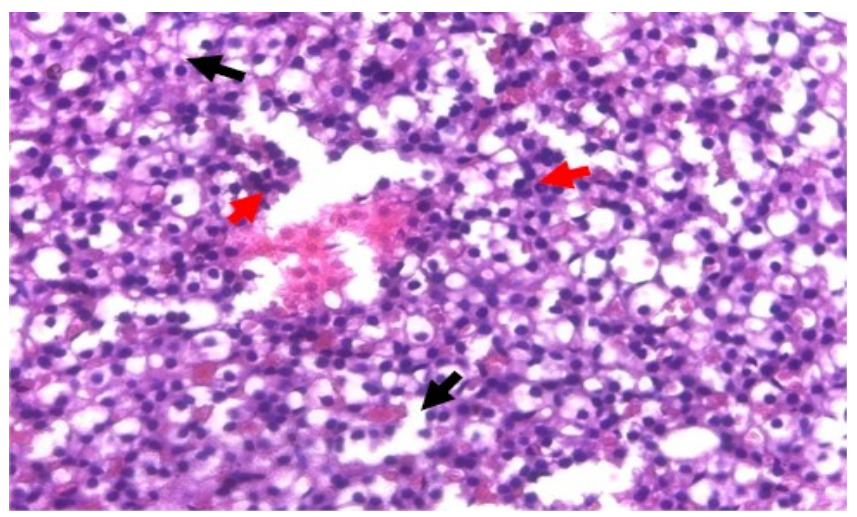

Fig. 13: Microphotograph of adrenal gland from treated rats with $15 \mathrm{mg} / \mathrm{kg}$.bw. showing necrosis $\rightarrow$ and infiltration of inflammatory cells $\rightarrow(\mathrm{H} \& \mathrm{E}, 200 \mathrm{x})$.

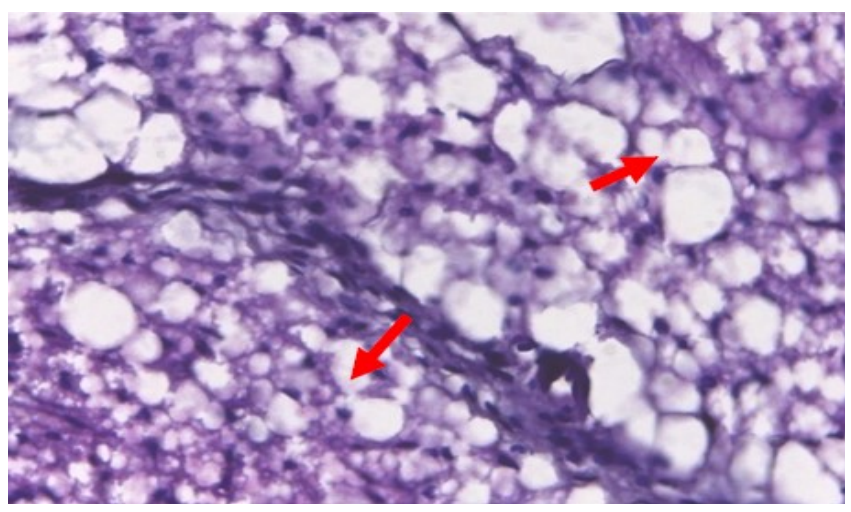

Fig. 14: Microphotograph of adrenal gland from treated rats treated with $15 \mathrm{mg} / \mathrm{kg}$.bw. showing adipocytes infiltration in medulla $\rightarrow(\mathrm{H} \& \mathrm{E}, 400 \mathrm{x})$.

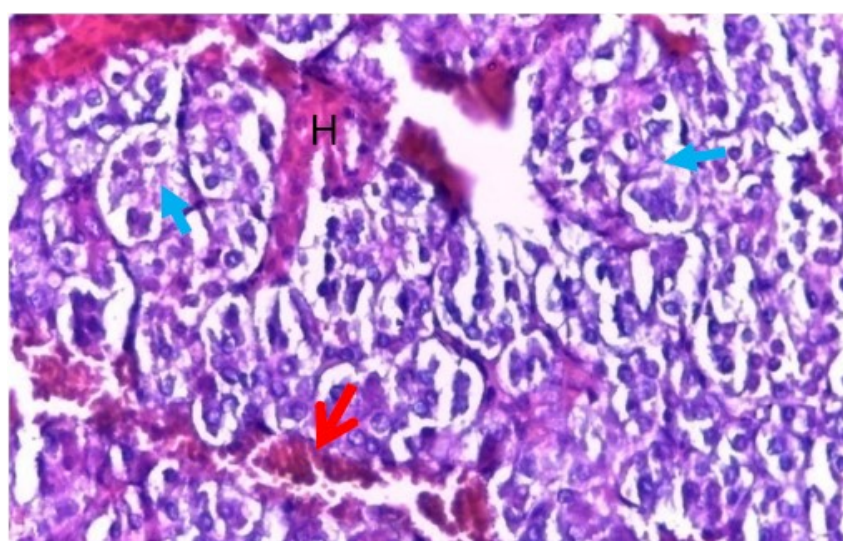

Fig. 15: Microphotograph of adrenal gland from treated rats with $20 \mathrm{mg} / \mathrm{kg}$.bw. showing congested blood vessels $\rightarrow$, hemorrhage $(\mathrm{H})$, degeneration and necrosis of fasciculata zona $\rightarrow$ (H\&E, 400x).

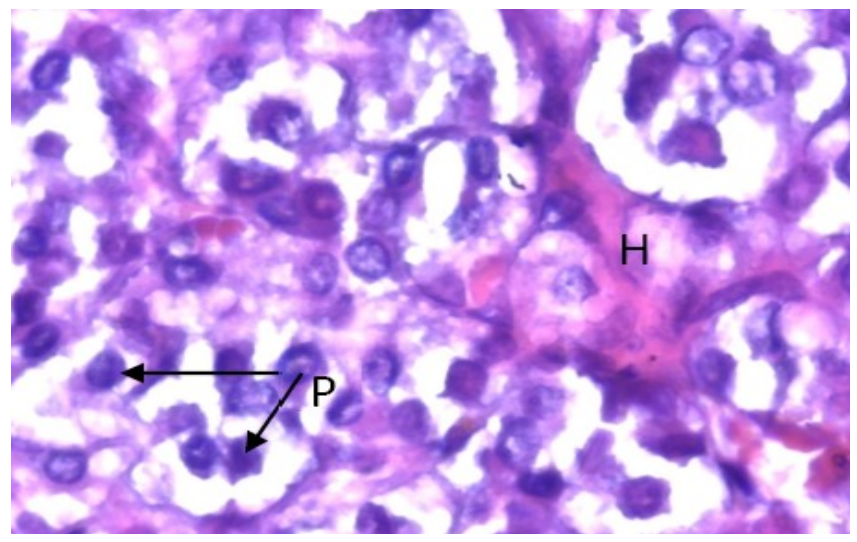

Fig. 16: Microphotograph of adrenal gland from treated rats with $20 \mathrm{mg} / \mathrm{kg}$.bw. showing pyknotic nuclei (P) and hemorrhage $(H),(H \& E, 600 x)$. 


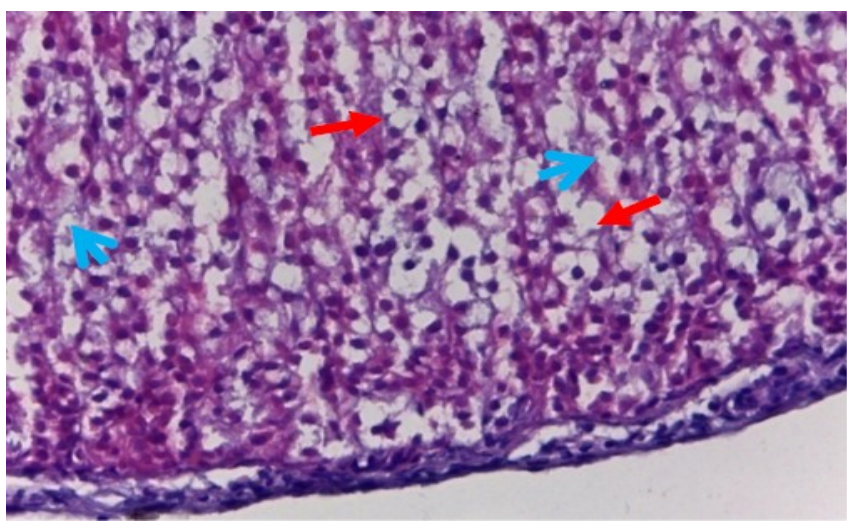

Fig. 17: Section in adrenal gland from treated rats with $20 \mathrm{mg} / \mathrm{kg}$.bw. showing pyknotic nuclei $\rightarrow$, degeneration and necrosis $\rightarrow$ of cells (H\&E, 400x).

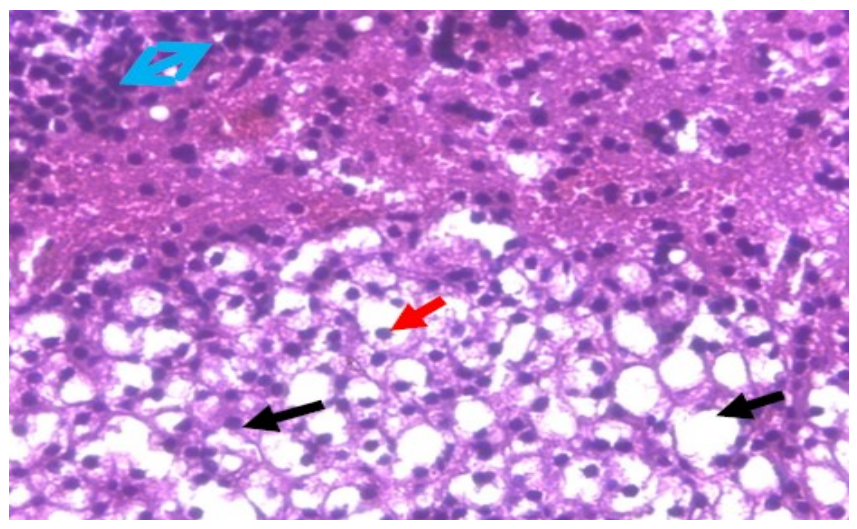

Fig. 18: Section in adrenal gland from treated rats with $20 \mathrm{mg} / \mathrm{kg}$.bw. showing pyknotic nuclei $\rightarrow$, infiltration of inflammatory cells $\underset{\rightarrow}{\longrightarrow}$, degeneration $\rightarrow$ (H\&E, 400x).

\section{Discussion}

In the current study, the cytotoxicity effects of orally administration of $\mathrm{CdCl}_{2}$ on the thyroid and adrenal glands in adult male rats were investigated. Cadmium is dangerous as it is easily absorbed and accumulated in tissues for very long time. The exposure to cadmium in low or high doses for long time may results in biochemical and functional alterations in some critical organs (16). The reported toxic effects induced by cadmium are similar to the effects of many other toxic metal (17). Cadmium metal exposure leads induction of reactive oxygen species (ROS) formation, for example, superoxide radical, hydroxyl ion and hydrogen peroxide (18). The reaction of reactive oxygen species with the cellular biomolecules has been shown to cause lipid peroxidation, membrane protein and DNA damage $(19,20)$. Marcinkiewicz, et al. (21) believed that the effects of cadmium on thyroid gland is by interfering with thyroid function at the glandular level as well as at peripheral level. The mechanisms of these effects is probably by inhibition the conversion of $\mathrm{T} 4$ to $\mathrm{T} 3$, in addition, cadmium may cause damages to the structure and function of both follicular and parafollicular cells resulting in the reduction of thyroidal uptake (22). Numerous studies suggested the mechanisms of the thyroid structural damages and malfunction which includes affecting thyroxin metabolism in liver is via the reducing of hepatic "Outer Ring Deiodinase ORD" activity. ORD is an enzyme responsible of converting the majority of the circulating form of thyroid hormone (T4) to the biologically active form (T3). The reduction of ORD leads to the disruption of $\mathrm{T} 3$ signaling which results in the reduction of $\mathrm{T} 4$ conversion (23). Elongated exposure to cadmium may stimulate the hepatic microsomal enzyme especially UDPGT (Uridine DiPhosphate Glucournyl Tranferase) and phenol sulftransferase activity $(24,25)$ resulting in fast clearance of T3 and T4. Cadmium accumulates in mitochondria of thyroid follicular epithelial cells, this may distract the oxidative phosphorylation of mitochondria with subsequent loss of energy supply which inhibits thyroid hormone synthesis and release (26). The adrenal glands are found to have the capacity to accumulate cadmium more than other endocrine gland (27). Many previous support the idea that the adrenal gland is highly susceptible to cadmium compare to other endocrine glands (28). Motabagani (29) demonstrated that cadmium many increase weight of the adrenal gland, moderate lipid depletion in the intracellular content of the zona glomerulosa, the decreased size of globules, may be resulted from an increase in the vascularity, glandular tissue hypertrophy and the increase of protein content within the cells. The current study showed that treatment of rats with cadmium chloride induced degenerative changes in the adrenal cortex in the form of vacuolation of the cytoplasm, increase in lipid droplets, and pyknosis of the nuclei. These findings are in agreement with previous investigators whose results correlated with the histological changes observed in the present study (30). Oxidative stress triggered by different metals may destructe certain tissues and release various transaminases into the plasma (31). Cadmium has the ability to affect the activation of numerous signaling pathways and produce reactive radicals. These radicals lead to oxidative stress state, subsequent DNA damage and lipid and protein oxidation $(32,33)$. Moreover, Cadmium may be associated with active oxygen species (ROS) production $(34,35) . \mathrm{Cd}$ is known to reduce both glutathione and protein-bound sulfhydryl groups, which results in enhancing the production of reactive oxygen species (ROS) such as superoxide ion, hydroxyl radicals and hydrogen peroxide (36). 


\section{References}

1. JÄRUP L. Cadmium overload and toxicity. Nephrol Dial Transplant. 2002;17(2):35-39.

2. World Health Organization. Environmental Health Criteria 134 : Cadmium. International Programme of Chemical Safety, Geneva; 1992.

3. Yoshizuka M, Mori N, Hamasaki K, Tanaka I, Yokoyama M, Hara K, Doi Y, Umez Y, Araki H, Sakamoto Y. Cadmium toxicity in the thyroid gland of pregnant rats. Exp Mol Pathol. 1991;55(1):97-104.

4. Gupta P, Kar A. Cadmium induced thyroid dysfunction in chicken; hepatic type I iodothyronine 5-D-I activity and role of lipid peroxidation. comp. Biochm Physiolo Pharmacol Endocrinol. 1999;123(1):39-44.

5. Bhattacharyya MH, Wilson AK, Rajan S, Jonah M. Biochemical pathways in cadmium toxicity. In: Zalup RK, Koropatnick J, Eds. Molecular Biology and Toxicology of Metals. London: Taylor and Francis. 2000;pp:1-74.

6. Wu SM, Shih MJ, Ho YC. Toxicological stress response andcadmium distribution in hybrid tilapia (Oreochromis sp.) uponcadmium exposure. Comp BiochemPhysiol C Toxicol Pharmacol. 2007;145(2):218-26.

7. Ramirez DC, Giménez MS. Varied protocols of cadmium exposure produce different effects on nitric oxide production in macrophages. Toxicol. 2000;146:61-72.

8. Lafuente A, Cano P, Esquifino A. Are cadmium effects on plasma gonadotropins, prolactin, ACTH, GH and TSH levels, dose dependent? Biometals. 2003;16:243-250.

9. Manca D, Ricard AC, Trottier B, Chevalier G. Studies on lipid peroxidation in rat tissues following administration of low and moderate doses of cadmium chloride. Toxicol. 1991;67:303-323.

10. Slater TF. Oxygen Free Radicals and Damage. Ciba Foundation Symposium 65 (new series). Amsterdam Excer Med. 1997;143-165.

11. Takiguchi M, Yoshihara S. New aspects of cadmium as endocrinedisruptor. Environ Sci. 2006;13(2):107-116

12. Iavicoli I, Fontana L, Bergamaschi A. The effects of metals asendocrine disruptor. J Toxicol Environ Health B Crit Rev. 2009;12(3):206-223.

13. Antonio MT, Benito MJ, Leret ML, Corpas I. Gestational administration of cadmium alters the neurotransmitter levels in newborn rat brains. J Appl Toxicol. 1998;18:83-88.

14. Borgeest C, Green feld C, Tomic D, Flaws JA. The effects of endocrine disrupting chemicals on the ovary. Front Bio Sci. 2002;7:1941-1948.

15. Luna LG. Manual of histological staining of force institute of pathology. 3rd Ed., McGraw hill book, New York. 1968;258:pp134135.

16. Grosicki A, Kowalski B. "Whole -body and organ retention of cadmium after reported administration to rats." Bull Vet Inst Pulawy. 2002;46:143-147.

17. Acharya U, Acharya S, Mishra M. Lead acetate induced cytotoxicity in Male germinal cells of Swiss rats. Industrial Health. 2003;41:291294.

18. Christopher O, Ikediobi V, Badisa L, Lambert T, Ayuk T, Lekan M, Latinwo J. West Response of antioxidant enzymes and redox metabolites to cadmium-induced oxidative stress in CRL-1439 normal rat liver cells. Internat J Molec Med. 2004;14:87-92.

19. Berleu BS, Stadiman ER, Protein oxidation in aging, diseases and oxidative stress, J Biol Chem, 1997;272:20313-20316.

20. Dally H, Hartwig A. Induction and repair inhibition of oxidative DNA damage by nickel and cadmium in mammalian cells. Carcinogenesis. 1997; 18:1021-1026.

21. Marcinkiewicz BP, Sawicki B, Brzbska MM, Moniuszko JJ. "Effect of chronic administration of cadmium on the rat thyroid radioimmunological and immunohistochemical studies." Folia Histochem. Cytobiol. 2003;40:95-96.

22. Barbara P. Structure and function of thyroid follicular cells in female rats chronically exposed to cadmium. Bull Vet Inst Pulawy. 2003;47:157-163.

23. Amma LL, Wong CZ, Venstrom B, Forrest D. Distinct tissue specific roles for thyroid hormone receptors $\beta$ and $\alpha$-inregulation of type 1deiodinase expression. Mole Endocrinol. 2001;15(3):467-475.

24. Wade MG, Sophi P, Kenneth W, Edward Y. Thyroid toxicity due to Subchronic exposure to a complex mixture of 16 organochlorines, lead, and cadmium. Toxicol Sci. 2003;67:207-18.

25. Ghosh E, Bhattacharya S. Thyrotoxicity of chlorides of cadmium and mercury in rabbits. Biomed Environ Sci. 1992;5(3):236-240.

26. Yoshizuko M, Mori N, Hamasaki K. Cadmium toxicity in throid gland of pregnant rats. Exp Mol Pathol. 1991;55(1)97-104.1.

27. Killmer WE. Uptake and retention of cadmium 109 in the pituitary, the adrenals and the thyroid of the laboratory rat. Internat J Appl Radio Isotopes. 1980;31:607-609.

28. Nishiyama S. Takata T. Effects of cadmium on the level of serum corticosterone and adrenocortical function in male and female rats. Res Commun Chem Pathol Pharmacol. 1982;37:65-80.

29. Motabagani MAH. Effect of Cadmium On The Morphology Of Adrenal Gland In Mice. J Anat Soc India. 2002;51(2):212-215

30. Pereira C, Mapuskar K, Vaman RC. A two generation chronic mixture toxicity study of Clophen A60 and diethyl phthalate on histology of adrenal cortex and thyroid of rats. Acta Histochem. 2007;109(1):2936.

31. Jackim E, Hamlin, JM, Sonis S. Effects of metal poisoning on five liver enzymes in the kill fish (Fundulusheteroclitus). J Fish Res Board Can. 1970;27,383-390.

32. Ognjanović BI, Markovic SZ, Pavlovic R, Zikic AS, Stajn ZS. Effect of chronic Cadmium exposure on antioxidant defense system in some tissues of rats : protective effects of Selenium. Pysiol Res. 2008;57:403-411.

33. 33.Valko M, Morris H, Cronin MTD. Metals, Toxicity and Oxidative stress. Curr Med Chem. 2005;12:1161-1208.

34. Szuster-Ciesielska A, Stachura A, Slotwinska M, Kaminska T, Sniezko R, Paduch R, Abramczyk D, Filar J, Kandefer-Szerszen M. The inhibitory effect of zinc on cadmium-induced cell apoptosis and reactive oxygen species (ROS) production in cell cultures. Toxicol. 2000;145:159-171

35. Liu J, Zheng BS, Vasken A. Chronic Arsenic poisoning caused by burning coal containing high arsenic in Guizhou province of China. Environ Health Persp. 2002;110:119-122.

36. Liu J, Shen HM, Ong CN. Role of intracellular thio depletion, mitochondrial dysfunction and reactive oxygen species in Salvia miltiorrhiza-induced apoptosis in human hepatoma HepG2 cells. Life Sci. 2001;69(16):1833-1850. 